\title{
ОСОБЛИВОСТІ ПЦДГОТОВКИ ЖІНОЦТВА У ПРАВОСЛАВНИХ МОНАСТИРЯХ УКРАЇНИ ДО ДУХОВНО-МОРАЛЬНОГО ВИХОВАННЯ МОЛОДОГО ПОКОЛІННЯ (ХІХ - ПОЧАТОК ХХ СТ.)
}

У статті проаналізовано особливості підготовки жіноцтва у православних монастирях України до духовно-морального виховання молодого покоління в XIX - на початку XX століття. При проведенні дослідження використано: історичні методи (історико-типологічний, історико-структурний, хронологічний, ретроспективний), щзо дозволили простежити розвиток питань, які вивчаються, в зазначений період; загальнонаукові (аналіз, синтез, систематизація, зіставлення, узагальнення) 3 метою з'ясування ступеня дослідженості проблеми, яка вивчається; порівняльно-змістовий, щзо дав змогу порівняти зміст, форми та методи підготовки жіноцтва у православних монастирях України до духовноморального виховання учнів у досліджуваний період.

Установлено, щзо в XIX - на початку XX століття в усіх навчальновиховних закладах Російської імперї (а також $і$ на украӥнських теренах, щуо входили до ї складу) духовно-моральне виховання здійснювалося $з$ обов'язковим урахуванням релігійних православних принципів. Метою навчання $і$ виховання в школах при монастирях було формування духовноморальної особистості, яка вірить у божественне створення світу, ианує все, щзо створене Богом.

Проаналізовані нами питання підготовки жіноцтва до духовноморального виховання підростаючого покоління, відзначаються співзвучністю педагогічних ідей минулих років із сучасністю, а саме: духовно-моральне виховання повинно будуватися на православних засадах; ефективній організації духовно-морального виховання сприяють такі форми позаурочної роботи, як: літературні вечори, вокально-літературні ранки, виставки, екскурсї, випуск училищних журналів та газет; при організації духовно-морального виховання учнів педагогічно доизільно використовувати такі методи виховання, як: переконання, позитивний приклад, нагадування, настанова, прохання, попередження, привчання (посилення волі), заохочення (нагороди) та покарання.

Доведено, щзо зміст, форми $і$ методи духовно-морального виховання ученицьь у монастирських школах визначеного періоду мали в иілому прогресивне значення. Зокрема, у навчальних програмах чітко визначався 
обсяг знань із кожної дисципліни за навчальними роками, конкретно формулювалися завдання та виховні иілі кожного курсу, розкривались методи його вивчення. Навчально-виховний процес будувався на основі принципів наочності $і$ доступності, послідовності та врахування вікових особливостей дітей.

Ключові слова: жіноцтво, духовно-моральне виховання, підготовка, православний монастир, підростаюче покоління.

Shtefan L. A., Kalina K. Ye. Peculiarities of preparation of womankind for spiritual and moral education of the young generation in orthodox monasteries of Ukraine (the $X I X^{\text {th }}$ - the beginning of the $X X^{\text {th }}$ century). The article analyzes the peculiarities of preparation of womankind for the spiritual and moral education of the young generation in the orthodox monasteries of Ukraine in the $X I X^{\text {th }}$-at the beginning of the $X X^{\text {th }}$ centuries. During the study we used: historical methods (historical-typological, historical-structural, chronological, retrospective), which allowed to trace the development of the issues under study in the specified period; general scientific (analysis, synthesis, systematization, comparison, generalization) in order to find out the degree of the study of the mentioned problem; comparative-semantic, which made it possible to compare the content, forms and methods of preparation of womankind for spiritual and moral education of students in the orthodox monasteries of Ukraine in the studied period.

It has been established that spiritual and moral education was carried out with the obligatory observance of religious orthodox principles in all educational institutions of the Russian Empire (as well as in the Ukrainian territories that were part of it) in the XIX ${ }^{\text {th }}$ - early XX ${ }^{\text {th }}$ centuries. The purpose of education and upbringing in the schools at the monasteries was to form a spiritual and moral personality who believes in the divine creation of the world, honors everything created by God.

The analyzed issues of preparing women for the spiritual and moral education of the younger generation are notable for the harmony of pedagogical ideas of past years with the present, namely:

spiritual and moral education should be based on the orthodox principles; effective organization of spiritual and moral education is promoted by such forms of extra-curricular work as: literary evenings, vocal and literary morning perfomances, exhibitions, excursions, school magazines and newspapers; it is pedagogically expedient to use such methods of education as: persuasion, positive example, reminding, instruction, request, warning, inurement (strengthening of will), encouragement (rewards) and punishment in organizing the spiritual and moral education of students.

It has been proved that the content, forms and methods of spiritual and moral education of the students in the monastic schools of the mentioned period were generally progressive. In particular, the curricula clearly defined the amount of knowledge from each discipline in the academic years, tasks and educational goals of each course were specifically formulated, methods of studying the course 
were revealed. The educational process was built on the principles of clarity and accessibility, consistency and taking into account the age characteristics of children.

Keywords: womankind, spiritual and moral education, preparation, orthodox monastery, younger generation.

Вступ. Для сучасної школи та держави характерна девальвація загальнолюдських цінностей, утрата виховного ідеалу. Зазначені чинники негативно впливають на виховання молоді взагалі та їі духовно-моральне становлення зокрема.

Проблема виховання сучасних учнів належить до питань загальнодержавного масштабу. Це положення знайшло своє відбиття в державних національних програмах «Діти України» (2012), «Виховання дітей та учнівської молоді в Україні» (2004), «Концепції виховання особистості в умовах розвитку української державності» (2016) та деяких ін.

Дієву допомогу в реалізації питань духовно-морального виховання особистості може надати вивчення та творче використання педагогічно цінних ідей щодо особливостей підготовки жіноцтва у православних монастирях до зазначеного виховання підростаючого покоління XIX початку XX століття, коли було накопичено оригінальний зміст, форми та методи організації такого виховання.

Вивченню питань духовно-морального виховання особистості присвячені дисертації з історії педагогіки (В. Карагодін - релігійно-моральне виховання, В. Мірошниченко - монастирське виховання, Т. Тхоржевська, Г. Шестун - православне виховання, В. Фазан - духовне виховання).

Мета та завдання. У статті проаналізовано зміст, форми та методи підготовки жіноцтва у православних монастирях України до духовноморального виховання учнів XIX - початку XX століття.

Методи дослідження. При проведенні дослідження використано: історичні методи (історико-типологічний, історико-структурний, хронологічний, ретроспективний), що дозволили простежити розвиток питань, які вивчаються, в зазначений період; загальнонаукові (аналіз, синтез, систематизація, зіставлення, узагальнення) 3 метою 3'ясування ступеня дослідженості проблеми, яка вивчається; порівняльно-змістовий, що дав змогу порівняти зміст, форми та методи підготовки жіноцтва у православних монастирях України до духовно-морального виховання учнів у досліджуваний період.

Результати. Вивчення та узагальнення науково-педагогічних джерел свідчить про те, що жіночі освітні заклади, які діяли при монастирях України 
в XIX - на початку XX ст., були покликані здійснювати підготовку високоморальних, суспільно значимих, соціально активних громадян.

Монастирські школи мали безпосереднє, чітке керівництво з боку Церкви. У досліджуваний період у монастирських школах вивчалися такі предмети, як: Закон Божий; священна історія Старого і Нового Завіту; церковна історія; катехізис; особливості богослужіння; церковний спів; російська мова; церковнослов'янська мова; церковна та вітчизняна історія; географія; арифметика; каліграфія 3 малюванням; дидактика; геометричне креслення і землемірство; бесіди про предмети та явища природи.

Окрім зазначених дисциплін до програми монастирських шкіл могли додаватися такі предмети - викладання ремесел, окремих галузей сільського господарства, рукоділля (вивчалось у жіночих школах). Основним предметом був Закон Божий, котрий утверджував у дітей моральні ідеали (Pobedonoscev, 1897).

Зокрема, обер-прокурор Святійшого Синоду К. Побєдоносцев, убачав завдання монастирської школи не тільки в розумовій освіті, а, насамперед, у вихованні «моральних і релігійних людей за законами православної церкви» (Pobedonoscev, 1886).

Цю думку урядовця цілком поділяла і Церква. Починаючи 31884 року, мета монастирської школи об’єднувала такі складові, як:

- виховання почуття «відданості» та любові до Царя і Вітчизни;

- прищеплення дітям страху Божого і розвиток у них почуття любові та благоговіння до Бога;

- утвердження в дітях необхідності належного виконання християнських обов'язків;

- пробудження християнської любові до ближнього, батьків та старшим за віком;

- викорінення у дітях поганих звичок i прищеплення їм правил благочестивої поведінки;

- чітке, розумне та грунтовне викладання корисних знань, які необхідні будуть учням на все життя (Spasskij, 1889).

У становленні та розвитку монастирських шкіл у другій половині XIX століття разом із церковними діячами активну участь брали педагогічні кадри. Зокрема, відомий педагог М. Ільминський сформулював думку про те, що моральність і релігія $є$ фундаментом духовності всіх народів. Педагог наголошував, що діти можуть легко сповнитися благоговінням і слухають богослужіння «добрим серцем і благим». 3 огляду на це, вони матимуть багате духовне життя тільки тоді, коли школа буде тісно працювати 3 Церквою (Shestun, 2001). 
Варто наголосити на тому, що діяльність монастирських шкіл другої половини XIX століття мала прогресивне значення. Цьому сприяли навчальні програми з предметів, які орієнтували вчителя на творчі пошуки.

У відповідності 3 «Правилами про церковнопарафіяльні школи» (1884 р.) існувало два типи монастирсько-парафіяльних шкіл. Це: однокласні (з дворічним курсом навчання) і двокласні (з чотирирічним курсом).

Необхідно також підкреслити, що монастирські школи (однокласні і двокласні) були найпоширенішим типом духовного навчального закладу досліджуваного періоду. За новим «Положенням про церковні школи» (1902 р.), навчання в однокласних монастирських школах було збільшено до трьох років, а у двокласних - до п'яти (Polozhenie o cerkovnyh shkolah vedomstva pravoslavnogo ispovedanija, 1902).

У монастирських школах навчальний рік тривав, як правило, від семи до дев'яти місяців. Заняття проходили з 15 вересня до 15 травня. Прийом дітей до школи здійснювався перед початком занять протягом двох тижнів. Якщо учень пропустив школу понад тридцяти днів, то він уважався відрахованим зі школи (Farmakovskij, 1898).

Методика викладання у школах при монастирях об'єднувала педагогічні напрацювання церковних і світських учителів. Найбільша увага приділялася вивченню Закону Божого, священної історії, вчення про богослужіння та катехізису.

Крім зазначених предметів у монастирських школах викладався церковний спів, який включав спів «на слух» та по нотам. До обов’язкових для вивчення предметів також належали церковнослов'янська грамота, уроки російської мови та арифметики (Spasskij, 1889).

Важливим завданням діяльності монастирської школи був розвиток релігійно-морального почуття учнів. Основним предметом, який сприяв реалізації зазначеної мети був Закон Божий. На цих уроках учні вивчали істини православної віри, вчилися правильно молитися (Smirnov, 1899).

Починаючи з 1886 року, у монастирських школах велика увага приділялась класній молитві, якою супроводжувалися заняття з Закону Божого. Спочатку молитву читав учитель, а потім читали учні, по черзі (Sbornik metodicheskih raz\#jasnenij po predmetam, prepodavaemym v shkolah CP i gramoty, 1900).

Заняттям із вивчення Закону Божого у кожній групі відводилося шість уроків на тиждень. Основним методом навчання був питальновідповідальний, котрий розвивав увагу дітей і сприяв концентрації iі на навчальному предметі. 
Закон Божий, як правило, викладався архімандритом, ігуменом та священиком, які закінчили курс духовної семінарії. До функцій законовчителів також належали: керівництво викладанням усіх предметів, організація навчально-виховного процесу, перевірка знань учнів, звітність по школах, складання планів проведення занять, контроль за відвідуванням школи учнями, за їхньою поведінкою тощо.

Велике значення для духовного, морального та естетичного виховання молоді мав церковний спів, який налаштовував школярів на духовний настрій, робив їх сприйнятливими до краси церковної служби. «Спів, наголошував С. Рачинський, - єдина галузь навчання, в якій успіхи можуть бути оцінені навіть неписьменними батьками учнів. I вчитель, здатний влаштувати в Церкві пристойний спів, мав величезну перевагу перед своїми побратимами» (Rachinskij, 1883).

Як свідчить проведене дослідження, вихованки монастирських шкіл обов'язково відвідували храм Божий у недільні та святкові дні, готувалися до Таїнств Причастя.

Кількість учнів у монастирських школах зростала щорічно. Діти, які виховувались у зазначених школах, позитивно впливали на своїх батьків $\mathrm{i}$ знайомили їх із знаннями про Бога, моральність, церковну службу та добрі звичаї. Батьки, відвідуючи храм, цікавилися тим, що́ там співалося, читалося, проповідувалося і більше розуміли почуте й побачене (Fal'bork, 1900).

Отже, навчальний план монастирських шкіл грунтувався на вивченні релігії, на гуманістичних і реалістичних засадах освіти.

Викладання у школах при монастирях велося за програмами та навчальними посібниками, які були визначені Правлячим Синодом і служили керівництвом для законовчителів і вчителів. У зазначеній літературі вказувалися відомості про обсяг дисципліни, ії̈ зв'язок з іншими, визначалась виховна мета уроку, а також надавалися конкретні рекомендації щодо викладання предметів (Cirkuljar Uchilishhnogo soveta pri Sv. Sinode, 1891).

Проте для досягнення мети духовно-морального виховання учнівської молоді знань у галузі релігії та християнських чеснот було недостатньо, тому що істини християнської віри повинні пройти крізь серце та визначити життя й подальшу поведінку учнів. Для цього необхідно було відповідним чином улаштувати і саме монастирське життя та завести в школі такі порядки, за яких усі вихованки мали виконувати конкретні релігійно-моральні обов'язки через які набували добру поведінку та виховувались у християнських традиціях.

Варто наголосити на тому, що дисципліна в школах при монастирях була важливим виховним чинником і виявлялася не лише в дотриманні 
зовнішнього порядку в школі, а й у достойній поведінці учнів (слухняність, старанність, акуратність у заняттях, добрі успіхи у навчанні). До засобів, які виховували дисципліну, належали: особистий приклад наставника, метод змагання, заохочення та покарання.

Запорукою шкільного порядку слушно вважався авторитет учителя та любов учнів до нього. На думку К. Побєдоносцева, для досягнення поваги своїх вихованців учитель повинен «впливати на учнів не гнівом i жорстокістю, а ласкавістю і страхом, пристосовуватися на уроках до сил i розуміння кожного» (Pobedonoscev, 1901).

Щоб діти не втомлювалися на уроках, до занять висувались певні вимоги, а саме: вони мали бути не дуже довгими й не короткими; більш складні предмети в розкладі рекомендувалось ставити так, щоб у дітей ще були розумові сили, а на час стомлення радилось планувати уроки з більш легких дисциплін; під час викладу матеріалу рекомендувалось не захоплюватися тільки поясненнями, а перериватися, проводити опитування.

Взагалі духовно-моральне виховання у монастирських школах проводилось методами, які відомі і у світській педагогіці, але суттєвою особливістю застосування цих методів було залучення до виховного процесу всіх здібностей дитячої душі - розуму, волі та почуттів. Зокрема, у школах при монастирях поширення набули такі методи виховання, як: переконання, позитивний приклад, нагадування, настанова, прохання, попередження, привчання (посилення волі), заохочення (нагороди) та покарання. До провідних методів покарання в досліджуваний період належали: методи покарання поглядом, жестом; покарання словом (зауваження чи попередження, яке висловлювалось наодинці); покарання справою (стояння за партою або біля столу вчителя, позбавлення певного задоволення).

Велике значення у школах при монастирях надавалося вихованню почуття «страху Божого», яке виражалося у відчутті присутності Бога, побоюванні образити Його недостойними вчинками. Вважалося, що страх Божий є основою мудрості, а потім уже свою позитивну роль відіграють добрий приклад та відповідне оточення.

Використання того чи іншого методу впливу на вихованок у монастирських школах пояснювалось турботою про розвиток у них i почуттів морального обов'язку, сумлінності, стриманості, покори, дружелюбності у стосунках, скромності, а також формування добрих навичок у праці.

Учителі також дбали про виховання в учнях правдивості, оскільки саме прагнення до істини є джерелом усіх чеснот. Педагог сам мав бути взірцем 
правдивості. У школі категорично заборонялося вимовити слова неправди, навіть жартома, оскільки неправда ображає Господа.

Виховання скромності мало оберігати дітей від таких моральних вад, як: марнославство, гординя, хвастощі. Хлопчиків та дівчаток 3 дитячого віку привчали не засуджувати чужих вчинків i постійно викорінювали щонайменші прояви самолюбства.

Моральне виховання майбутніх учительок, як і релігійне, грунтувалося на засадах православної віри. Воно було покликане закласти в свідомість вихованок обов'язковість дотримання євангельського морального закону й утвердження в їхніх душах міцного фундаменту для виконання цього закону в подальшому житті. 3 огляду на це, в ученицях виховували ввічливість, повагу до старших, необразливе та щире ставлення до подруг, поблажливість до молодших і немічних. Особливо важливим у моральному вихованні жінок уважалося привчання їх до щирості, до подолання самолюбства та до зваженості у вчинках.

Духовно-моральному розвитку вихованок сприяла і організація масових форм позаурочної роботи, таких як: літературні вечори, вокально-літературні ранки, виставки, екскурсії, випуск училищних журналів та газет. Проведення зазначених заходів утверджувало у свідомості учениць важливі християнські поняття (взаємодопомога, милосердя, дружелюбність, ввічливість, повага та чуйність у ставленні до інших людей).

Необхідно звернути увагу і на те, що позаурочний час призначався для проведення самостійної роботи вихованок - написання домашніх письмових творів і позакласного читання. Твори писалися практично з усіх навчальних дисциплін, а саме: з Закону Божого, словесності, історії, дидактики, географії та фізики. Основними критеріями при оцінюванні твору вважалися виклад матеріалу літературною мовою та відповідність змісту заявленій темі. Найвища оцінка виставлялась за чіткість думки та послідовність їі розкриття, стилістичну і граматичну правильність викладу матеріалу.

Вивчення та узагальнення науково-педагогічних джерел свідчить про те, що у 1907 році до начальних планів дівочих монастирських шкіл було внесено певні зміни, а саме: збільшено кількість уроків алгебри, природознавства, креслення, а також малювання та рукоділля, додано годин i на вивчення російської мови та літератури, історії, геометрії, фізики та дидактики. Такий стан речей вимагав перебудови занять вихованок, тобто запровадження нової системи, яка передбачала проведення по п’ять уроків щодня (Programma reform P. A. Stolypina, 2002).

Взагалі в кінці XIX - на початку XX століття в усіх навчально-виховних закладах Російської імперії (а також і на українських теренах, що входили до 
iï складу) духовно-моральне виховання здійснювалося 3 обов'язковим урахуванням релігійних православних принципів. Метою навчання i виховання в школах при монастирях було формування духовно-моральної особистості, яка вірить у божественне створення світу, шанує все, що створене Богом, сповідує любов до Нього, до Його церкви і до людей - в усіх iї проявах.

Обговорення. Отже, проаналізовані нами питання підготовки жіноцтва до духовно-морального виховання підростаючого покоління, відзначаються співзвучністю педагогічних ідей минулих років із сучасністю, а саме: духовно-моральне виховання повинно здійснюватися 3 урахуванням православних принципів; ефективній організації духовно-морального виховання сприяють такі форми позаурочної роботи, як: літературні вечори, вокально-літературні ранки, виставки, екскурсії, випуск училищних журналів та газет; при організації духовно-морального виховання учнів педагогічно доцільно використовувати такі методи виховання, як: переконання, позитивний приклад, нагадування, настанова, прохання, попередження, привчання (посилення волі), заохочення (нагороди) та покарання.

Висновки. Зміст, форми i методи духовно-морального виховання учениць у монастирських школах визначеного періоду мали в цілому прогресивне значення. Зокрема, у навчальних програмах чітко визначався обсяг знань із кожної дисципліни за навчальними роками, конкретно формулювалися завдання та виховні цілі кожного курсу, розкривались методи його вивчення. Навчально-виховний процес будувався на основі принципів наочності і доступності, послідовності та врахування вікових особливостей дітей.

\section{ЛІТЕРАТУРА:}

Победоносцев К. П. Всеподданнейший отчет обер-прокурора Св. Синода по ведомству православного исповедания. Пб., 1886. 196 с.

Победоносцев К. П. Московский сборник. 4-е изд., доп. М. : Синод. тип., 1897. 331 с.

Победоносцев К. П. Ученье и учитель : педагогические заметки. М., 1901. 115 с.

Положение о церковных школах ведомства православного исповедания. СПб., 1902. 35 с.

Программа реформ П. А. Столыпина. Документы и материалы. О введении всеобщего начального обучения в Российской империи Т. 1 М.: «Российская политическая энциклопедия», 2002. С. 25.

Сборник методических разъяснений по предметам, преподаваемым в школах ЦП и грамоты. 2-е изд. СПб., 1900. 331 с.

Смирнов П. А. Народное образование и церковноприходская школа. СПб., 1899. 126 с.

Спасский П. Н. Сборник правил о школах церковноприходских с относящимися к ним определениями и указаниями Св. Синода. СПб., 1889. 84 с.

Фальборк Г. А. Народное образование в России. СПб., 1900. 264 с.

Фармаковский В. И. Статистические сведения по начальному образованию в Российской империи. Вып. 1. СПб., 1898. 183 с. 
Циркуляр Училищного совета при Св. Синоде. СПб., 1891. 11 с.

Шестун Е. Православная педагогика. М. : Православная педагогика, 2001. 560 с.

\section{REFERENCES:}

Pobedonoscev, K. P. (1886) Vsepoddannejshij otchet ober-prokurora Sv. Sinoda po vedomstvu pravoslavnogo ispovedanija. [The Most Substantial Report of the Chief Prosecutor of the Holy Synod on the Department of Orthodox Confession]. Pb., 196 s. (in Russian).

Pobedonoscev, K. P. (1897) Moskovskij sbornik. [Moscow collection]. 4-e izd., dop. M. : Sinod. tip., 331 s. (in Russian).

Pobedonoscev, K. P. (1901) Uchen'e i uchitel' : pedagogicheskie zametki. [Learning and teacher: pedagogical notes]. M., 115 s. (in Russian).

Polozhenie o cerkovnyh shkolah vedomstva pravoslavnogo ispovedanija. (1902). [The Regulation on Church Schools of the Department of Orthodox Confession]. SPb., $35 \mathrm{~s}$. (in Russian).

Programma reform P. A. Stolypina. (2002). Dokumenty i materialy. O vvedenii vseobshhego nachal'nogo obuchenija $\mathrm{v}$ Rossijskoj imperii [Documents and materials. On the introduction of universal primary education in the Russian Empire]. T. 1 M.: «Rossijskaja politicheskaja jenciklopedija», S. 25. (in Russian).

Rachinskij, S. A. (1883). Zametki o sel'skih shkolah. [Notes on rural schools]. SPb., 123 s. (in Russian).

Sbornik metodicheskih raz\#jasnenij po predmetam, prepodavaemym v shkolah CP i gramoty (1900). [A collection of methodological explanations on subjects taught in schools of CPU and literacy]. 2-e izd. SPb., 331 s. (in Russian).

Smirnov, P. A. (1899). Narodnoe obrazovanie i cerkovnoprihodskaja shkola. [Public education and parish school]. SPb., 126 s. (in Russian).

Spasskij, P. N. (1889). Sbornik pravil o shkolah cerkovnoprihodskih s otnosjashhimisja k nim opredelenijami i ukazanijami Sv. Sinoda. [Collection of rules on parish schools with related definitions and instructions of the Holy Synod]. SPb., 84 s. (in Russian).

Fal'bork, G. A. (1900). Narodnoe obrazovanie v Rossii. [Public education in Russia]. SPb., 264 s. (in Russian).

Farmakovskij, V. I. (1898). Statisticheskie svedenija po nachal'nomu obrazovaniju v Rossijskoj imperii. [Statistical information on primary education in the Russian Empire]. Vyp. 1. SPb., 183 s. (in Russian).

Cirkuljar Uchilishhnogo soveta pri Sv. Sinode. (1891). [The circular of the School Council under the Holy Synod]. SPb., 1891. 11 s. (in Russian).

Shestun, E. (2001). Pravoslavnaja pedagogika. [Orthodox pedagogy]. M. : Pravoslavnaja pedagogika, 560 s. (in Russian).

Інформація про авторів:

Штефан Людмила Андріївна: ORCID: https://0000-0002-6281-980X; доктор педагогічних наук, професор, завідувач кафедри історії педагогіки і порівняльної педагогіки Харківського національного педагогічного університету імені Г.С. Сковороди,

вул. Валентинівська, 2, м. Харків,

Україна, 61166.

e-mail: Valeriy.61.sh@gmail.com

\section{Каліна Катерина Євгенівна:}

ORCID:

https://0000-0002-4252-7690;
Information about the authors: Shtefan Liudmyla Andriivna:

ORCID: https://0000-0002-6281-980X; Dr. hab. in Pedagogy, Professor, the Head of History of Pedagogy and Comparative Pedagogy Department, H. S. Skovoroda Kharkiv National Pedagogical University, Valentynivska street, 2, Kharkiv, Ukraine 61166

e-mail: Valeriy.61.sh@gmail.com

Kalina Kateryna Yevheniivna:

ORCID: https://0000-0002-4252-7690; PhD 
кандидат педагогічних наук, доцент, in Pedagogy, Docent, Associate Professor of доцент кафедри історії педагогіки i History of Pedagogy and Comparative порівняльної педагогіки Харківського Pedagogy Department, H.S. Skovoroda національного педагогічного університету Kharkiv National Pedagogical University, імені Г. С. Сковороди, вул. Valentynivska street, 2, Kharkiv, Ukraine, Валентинівська, 2, м. Харків, Україна, 61166.

61166.

e-mail: kalinahnpu@gmail.com

e-mail: kalinahnpu@gmail.com

Цитуйте цю статтю як: Штефан Л.А., Каліна К.Є. Особливості підготовки жіноцтва у православних монастирях України до духовно-морального виховання молодого покоління (XIX - початок XX ст.). Теорія та методика навчання та виховання. 2019. № 47. С. 190200.

DOI: $10.34142 / 23128046.2019 .47 .17$

Дата надходження статті до редакції: 31.10.2019

Стаття прийнята до друку: 07.11.2019 